http://journal.uhamka.ac.id/index.php/syukur

\title{
PELATIHAN KEUANGAN SYARIAH DI SEKOLAH MENENGAH KEJURUAN (SMK) MUHAMMADIYAH CIANJUR
}

\author{
Hera Khairunnisa $^{1}$, Edi Setiawan ${ }^{2}$, \\ ${ }^{12}$ Universitas Muhammadiyah Prof. DR. HAMKA
}

Email: hera.khairunnsia@gmail.com¹, edisetiawan@uhamka.c.id ${ }^{2}$

Diterima: 9 Agustus 2018, Direvisi: 13 Agustus 2018, Disetujui: 23 Agustus 2018

\begin{abstract}
ABSTRAK
Tujuan dari kegiatan Pengabdian Kepada Masyarakat (PKM) ini adalah untuk memberikan pengetahuan dasar ekonomi syariah bagi siswa-siswa Sekolah Menengah Kejuruan (SMK) Muhammadiyah Cianjur. Tujuan kegiatan PKM ini didorong oleh ketiadaan program ekonomi yang berpotensi memfasilitasi dan memberi wawasan keuangan syariah. Wawasan keuangan syariah patut untuk diketahui siswa SMK Muhammadiyah sebab siswa-siswa SMK tersebut merupakan SDM yang potensial dalam mendukung perkembangan lembaga keuangan syariah di Indonesia. Solusi nyata yang diberikan dalam kegiatan PKM ini adalah pelatihan keuangan syariah yang dipaparkan melalui metode workshop yang berisikan pemarapan materi dari pembicara serta sesi tanya jawab. Materi pelatihan keuangan syariah ini yaitu sejarah perkembangan ekonomi islam, lembaga keuangan syariah, akad-akad transaksi syariah, dasar akuntansi syariah, dan pengenalan laporan keuangan syariah.
\end{abstract}

Kata kunci: ekonomi syariah, keuangan syariah, pelatihan, SMK.

\section{ABSTRACT}

The purpose of this Community Service Activity (PKM) is to provide basic Islamic economic knowledge for students of the Muhammadiyah Cianjur Vocational High School (SMK). The purpose of this PKM activity is driven by the absence of an economic program that has the potential role. Islamic financial insights are worthy of being known by Muhammadiyah Vocational High School students because these Vocational High Schools are potential human resources in supporting the development of Islamic financial institutions in Indonesia. The real solution given in this PKM activity is Islamic financial training which is proven through the workshop method which contains the material from the speaker and the discussion session. The Islamic financial training materials are the history of Islamic economic development, Islamic financial institutions, sharia transaction agreements, the basis of Islamic accounting, and the introduction of Islamic financial reports.

Keywords: Islamic economic, islamic financial, workshop, SMK. 


\section{PENDAHULUAN}

Sistem ekonomi islam atau ekonomi syariah di dunia berkembang pesat, tidak terkecuali di Indonesia (Widiana, 2017). Perkembangan tersebut disebabkan mayoritas penduduk Indonesia beragama muslim (Widiana, 2017). Sistem ekonomi islam di Indonesia telah diterapkan pada tahun 90-an (Maharani, Nuraini, dan Andrianto, 2017). Ekonomi islam mulai dikenal masyarakat pada tahun 1992 yaitu dengan pendirian Bank Muamalat yang kemudian diiringi dengan berbagai pendirian lembaga keuangan islam lainnya (Maharani, Nuraini, dan Andrianto, 2017).

Selain pendirian Bank Muamalat terdapat sebelas unit bank syariah yang memiliki kantor sebanyak 1.319 serta terdapat Bank Umum Konvensional yang memiliki 23 Unit Usaha Syariah (UUS) dan 321 kantor pada Juni 2011 (Rahmanti, 2012). Sampai dengan Juni 2011 terdapat 154 Bank Pembiayaan Rakyat Syariah (BPRS) di Indonesia yang beroperasi di tiga ratus kantor. Kuantitas lembaga keuangan syariah tidak hanya meningkat di sampai dengan tahun 2011 saja, namun berlanjut sampai dengan tahun 2012 dengan prestasi yang cukup membanggakan (Rahmanti, 2012).

Perkembangan pendirian lembaga keuangan syariah di Indonesia tentunya harus diakomodasi dengan peraturan akuntansi yang memadai (Bustamam, Ibrahim, dan Saputra, 2015). Sehingga peraturan akuntansi berbasis syariah juga berkembang di Indonesia untuk mengakomodasi kegiatan operasional lembaga keuangan tersebut. Akuntansi syariah yang diterapkan di Indonesia harus mampu mengakomodasi kebutuhan masyarakat (Maharani, Nuraini, dan Andrianto, 2017). Akuntansi syariah akan membatu masyarakat khususnya praktisi di lembaga keuangan syariah atau perusahaan dengan basis ekonomi syariah terkait pencatatan, pengukuran, maupun penyajian laporan keuangan (Maharani, Nuraini, dan Andrianto, 2017).

Lembaga keuangan syariah tentu saja dituntut untuk menjalankan operasional sesuai akidah islam dan mampu menghasilkan laporan keuangan secara transaparan dan berkualitas. Tenaga ahli yang profesional dalam keuangan islam diperlukan untuk mendukung kegiatan operasional dan pembuatan laporan keuangan yang berkualitas (Maharani, Nuraini, dan Andrianto, 2017). Rahmanti (2012) menjelaskan bahwa terdapat tantangan pada aspek Sumber Daya Manusia (SDM) yaitu tenaga ahli dalam menunjang kegiatan ekonomi syariah termasuk di Indonesia. Hal lain ditegaskan pula oleh Indriyanti, Siswandari, dan Ivada (2013) bahwa kualitas SDM dipandang sebagai salah satu faktor utama dalam era saat ini yaitu era perdagangan bebas.

Tantangan pada aspek SDM terlihat dari kurangnya pemahaman praktisi ekonomi syariah mengenai pengenalan karakteristik transaksi, produk dan jasa syariah, serta akad dalam transaksi syariah (Rahmanti, 2012). Oleh sebab itu, tenaga profesional tersebut harus didukung dengan pendidikan yang menunjang pula. Pendidikan ekonomi keuangan 
syariah sangat penting jika dimulai dari kegiatan perkuliahan yang menghadirkan mata kuliah akuntansi syariah (Maharani, Nuraini, dan Andriantro, 2017).

Hasil penelitian Maharani, Nuraini, dan Andrianto di 2017 membuktikan bahwa para dosen dan mahasiswa pada program studi akuntansi telah menyadari pentinganya penerapan mata ajar akuntansi syariah dalam kegiatan perkuliahan. Akuntansi syariah merupakan sistem akuntansi dengan menganut prinsip akuntansi islam. Akuntansi islam mengharuskan adanya pelaksanaan dan transaksi keuangan sesuai dengan akidah islam. Hasil penelitian Maharani, Nuraini, dan Andrianto (2017) juga didukung oleh Febrianto (2013) dalam Maharani, Nuraini, dan Andrianto (2017) yang menyatakan bahwa mata ajar akuntansi syariah diperlukan di perguruan tinggi baik bersifat wajib maupun pilihan.

Bidang akuntansi syariah tidak hanya diperlukan bagi jenjang perguruan tinggi negeri, namun dirasakan perlu juga bagi tingkatan pendidikan menengah seperti Sekolah Menengah Kejuruan (SMK). Berdasarkan data pokok Direktorat Pembinaan SMK yang diambil melalui datapokok.ditpsmk.net menjelaskan bahwa SMK memiliki berbagai kejuruan atau kompetensi seperti keuangan, administrasi perkantoran, budidaya perikanan, akuntansi, teknik komputer dan jaringan, pemasaran, dan sebagainya. Ada pula SMK yang membuka kejuruan perbankan

syariah seperti SMK Bhakti Nusantara Salatiga. SMK tersebut mendirikan jurusan tersebut dengan tujuan menghasilkan lulusan SMK yang ahli dan mampu bekerja di perbankan syariah.

SMK merupakan jenjang pendidikan formal yang memfokuskan pembelajaran pada pengembangan keterampilan siswa untuk melaksanakan suatu tugas atau pekerjaan tertentu (Indriyanti, Siswandari, dan Ivada, 2013). Setelah lulus dari jenjang SMK, siswa SMK dapat memilih untuk langsung bekerja atau melanjutkan pendidikan ke jenjang pendidikan tinggi.

Dari penjelasan di atas, dapat diasumsikan bahwa pendidikan akuntansi syariah diperlukan untuk menunjang tenaga profesional dalam menjalankan transaksi ekonomi berbasis syariah. Oleh sebab itu kami bermaksud untuk melaksanakan program pengabdian kepada masyarakat (PKM) dalam bentuk pelatihan akuntansi syariah untuk siswa SMK Muhammadiyah Cianjur.

SMK Muhammadiyah Cianjur memiliki jurusan diantaranya adalah jurusan teknik dan administrasi perkantoran. Jurusan tersebut tidak menjadi penghalang bagi kegiatan PKM ini sebab setiawan (2015) menjelaskan bahwa kinerja karyawan tidak dipengaruhi oleh latar belakang pendidikan karyawan tersebut. Meskipun tidak ada jurusan ekonomi atau akuntansi pada SMK Muhammadiyah Cianjur, namun peluan kerier siswa-siswa terbuka luas dalam sektor keuangan syariah. Pelatihan akuntansi syariah untuk siswa SMK ini bertujuan untuk memberikan pengetahuan dasar bagi siswa SMK. Karena siswa-siswa 
SMK merupakan calon SDM yang potensial dalam mendukung praktik usaha lembaga keuangan syariah di Indonesia.

\section{MASALAH}

Berdasarkan pendahuluan tersebut dapat diungkapkan beberapa masalah yang umumnya dihadapi oleh pihak mitra yaitu SMK Muhammadiyah Cianjur, antara lain:

1. Tidak adanya mata pelajaran mengenai keuangan syariah

2. Kurangnya kegiatan sosialisasi terkait keuangan syariah.

\section{METODE}

Kegiatan PKM ini dilaksanakan di SMK Muhammadiyah Cianjur yang berlokasi di Cianjur, Jawa Barat. Bentuk dari kegiatan PKM ini yaitu pelatihan keuangan syariah bagi siswa SMK. Sasaran dari kegiatan PKM ini adalah siswa-siswa SMK Muhammadiyah sebanyak lima puluh orang. Kegiatan PKM ini dilaksanakan dalam tiga tahapan metode yaitu tahap pra pelaksanaan, tahap pelaksanaan, dan tahap pasca pelaksanaan.

\section{Tahap Pra Pelaksanaan}

Kegiatan pada tahap pra pelaksanaan yaitu pemetaan masalah pada SMK Muhammadiyah. Pemetaan masalah dilakukan dengan komunikasi yang dilakukan secara tatap muka melalui survey pendahuluan serta melalui media elektronik. Permasalahan yang ditemukan adalah pihak SMK mengeluhkan kurangnya pengetahuan atau wawasan ekonomi atau keuangan syariah yang dipaparkan atau dikenalkan di lingkungan sekolah khususnya berupa kegiatan non formal diluar aktivitas pembelajaran rutin. Hal tersebut dikarenakan tidak adanya program ekonomi atau akuntansi pada SMK tersebut. Tidak adanya program ekonomi dan akuntansi tidak menyurutkan pihak SMK untuk menyalurkan SDMnya pada sektor lembaga keuangan syariah. Pada kegiatan survey juga diketahui mengenai waktu dan tempat kegiatan PKM.

\section{Tahap Pelaksanaan}

Pelaksanaan dilaksanakan pada 15 Mei 2018 bertempat di SMK Muhammadiyah Cianjur dan dihadiri oleh lima puluh orang peserta yang terdiri dari perwakilan seluruh jurusan kelas yang ada. Kegiatan pelaksanaan terdiri dari tiga sesi yaitu sesi perkenalan atau pendahuluan yang dipimpin oleh satu moderator atau pembicara. Sesi selanjutnya adalah sesi pemaparan materi yang dilaksanakan oleh tiga pembicara yang menyampaikan topik berbeda terkait keuangan syariah. Sesi terakhir adalah sesi diskusi atas topik yang telah dibahas. 


\section{Tahap Pasca Pelaksanaan}

Tahap ini berisi mengenai evaluasi kegiatan yang dilakukan oleh pihak pelaksana. Evaluasi kegiatan diperlukan sebagai perbaikan bagi kegiatan-kegiatan PKM berikutnya khususnya dalam membangung dan menciptakan SDM yang berkualitas dalam bidang keuangan syariah. Tahap pasca pelaksanaan juga merupakan tahap perwujudan luaran berupa penulisan karya ilmiah dari kegiatan PKM yang telah diselenggarakan ini.

\section{PEMBAHASAN}

Solusi yang ditawarkan dalam workshop ini kami sampaikan dengan menggunakan metode pendekatan pemberian informasi. Pemberian informasi tersebut kami sampaikan dalam bentuk pemaparan materi dan diskusi interaktif dengan siswa-siswa SMK. Proses diskusi interaktif tidak hanya memberikan kesempatan pada siswa-siswa tersebut untuk bertanya kepada tim pengusul namun tim pengusul juga bertanya ke siswa-siswa tersebut dalam konteks memastikan wawasan bahwa pemaparan materi telah tersampaikan dengan baik kepada siswa-siswa SMK Muhammadiyah Cianjur.

Menurut Data Pokok Pendidikan Dasar dan Menengah Direktorat Jenderal Pendidikan Dasar dan Menengah per 21 Agustus 2018 menjelaskan bahwa SMK Muhammadiyah Cianjur memiliki akreditasi A dan mengadpsi kurikulum 2013. Kegiatan pembelajaran dilakukan dalam lima hari di setiap pekan. Jumlah peserta didik lakilaki adalah 121 orang dan perempuan sebanyak 143 orang. SMK tersebut dilengkapi dengan Sembilan ruang kelas, satu ruang laboratorium, dan satu perpustakaan. Menurut website resmi dari SMK Muhammadiyah Cianjur, keahlian atau program pembelajaran yang tersedia yaitu rekayasa perangkat lunak, teknik komputer jaringan, dan administrasi perkantoran.

Program yang ada di SMK tersebut merupakan kompetensi unggulan yang diminati para siswa. Program administrasi perkantoran merupakan program yang paling diminati oleh siswi sekolah tersebut. Hal tersebut dikarenakan minat perempuan yang cenderung lebih menyukai karier dan pekerjaan sebagai officer. Di program administrasi perkantoran para siswa akan diberikan kompetensi mengenai administrasi, tata usaha, surat menyurat, dan lainnya.

Kegiatan PKM ini dilaksanakan pada hari Selasa tanggal 15 Mei 2018 bertempat di SMK Muhammadiyah Cianjur dari pagi hingga siang. Peserta dalam kegiatan tersebut yaitu sebanyak lima puluh orang. Pelaksanaan kegiatan ini dibagi menjadi tiga sesi sesi perkenalan atau pendahuluan yang diisi juga dengan sambutan oleh pihak guru SMK tersebut, sesi pemaparan materi, dan sesi tanya jawab atau diskusi. 


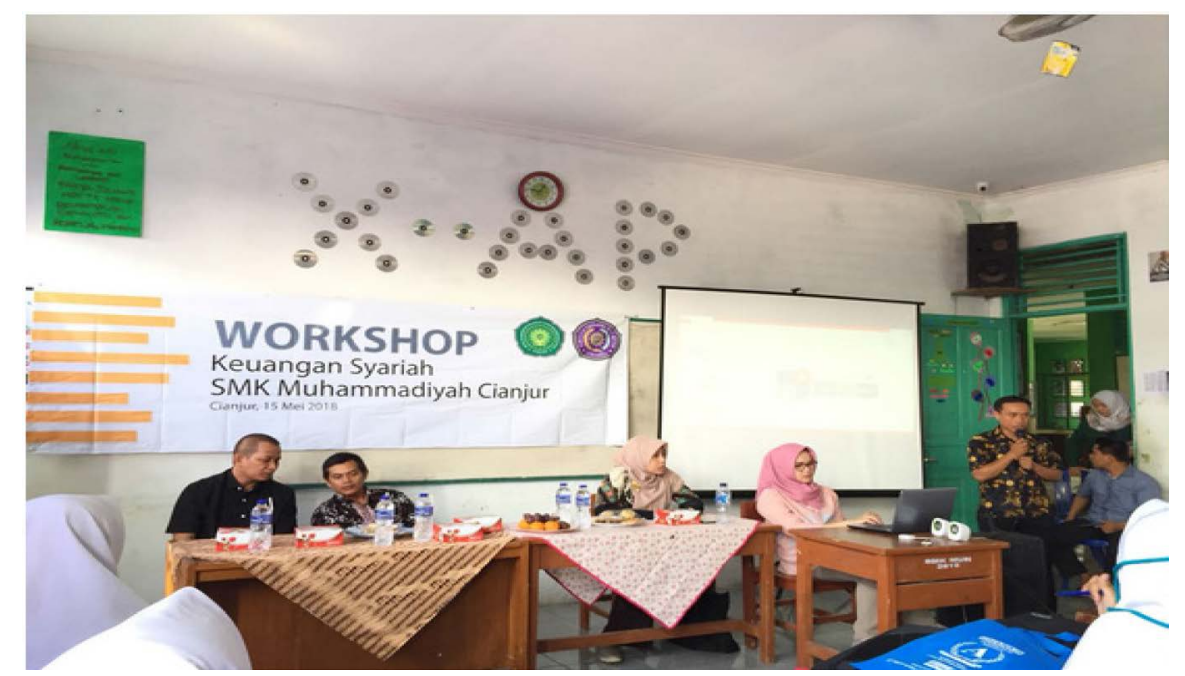

Sambutan dari Pihak Guru SMK Muhammadiyah Cianjur

Kegiatan yang dilaksanakan hari Selasa, 15 Mei 2018 ini menggunakan pendekatan pemaparan materi dan diskusi interaktif dimana materi disampaikan sesuai kebutuhan peserta. Untuk pemateri yang pertama diisi oleh Edi Setiawan, SE., MM, ahli dalam jurnalistik, ekonomi islam sekaligus Dosen FEB-UHAMKA. Materi yang disampaikan beliau adalah pemahaman mengenai sejarah dan perkembangan ekonomi islam. Tidak hanya itu beliau juga memberikan motivasi bagi siswa-siswa SMK Muhammadiyah dalam pemilihan karier khususnya di jalur usaha ekonomi islam. Hasil dari pemaparan materi ini yaitu peserta memiliki pemahaman mengenai sejarah ekonomi islam dan termotivasi untuk terjun ke dunia usaha ekonomi islam.

Bapak Edi Setiawan menjelaskan bahwa untuk terus membumikan ekonomi syariah diperlukan peran dari kaum muda. Siswa-siswa SMK merupakan salah satu kalangan masyarakat yang potensial untuk membumikan hal tersebut. Untuk terus membumikan ekonomi syariah dimulai dari pemakaian produk keuangan syariah. Bapak Edi juga menyarankan agar siswa-siswa turut aktif dalam kegiatan dan kajiankajian keislaman karena dalam kajian tersebut mereka dapat mengenal lebih dalam lagi mengenai keuangan dan ekonomi syariah.

Adapun materi kedua disampaikan oleh Hera Khairunnisa yang memiliki pengalaman praktik dan pengajaran dalam bidang akuntansi khususnya akuntansi keuangan. Beliau memberikan pemahaman mengenai latar belakang ekonomi syariah, lembaga keuangan syariah, manfaat keuangan syariah, dan jenis akad dalam transaksi keuangan syariah. Hasil dari pemaparan materi ini peserta mampu mengetahui tentang latar belakang ekonomi syariah, lembaga keuangan syariah, manfaat keuangan syariah, dan jenis akad transaksi syariah.

Menurut Kerangka Dasar Penyusunan dan Penyajian Laporan Keuangan 
Syariah (KDPPLK Syariah) transaksi syariah harus didasari oleh prinsip persaudaraan, keadilan, kemaslahatan, keseimbangan, dan universalisme. Karakteristik transaksi yang diperbolehkan secara syariah islam adalah tidak mengandung unsur riba, kezaliman, maysir, gharar, dan haram. Sofyan, Wiroso, dan Yusuf (2010) menjelaskan macam-macam prinsip transaksi syariah seperti bagi hasil, penyertaan modal, jual beli, dan sebagainya. Prinsip transaksi tersebut merupakan prisip yang sesuai dengan ajaran islam dan hukum islam.

Transaksi sesuai syariah adalah transaksi yang bebas dari riba, secara bahasa riba artinya adalah tambahan. Secara umum bentuk riba adalah bunga yang dikenakan atas pinjaman nasabah atau pihak peminjam. Pihak peminjam wajib mengembalikan uang yang dipinjam pada jumlah tertentu setelah ditambahkan oleh tambahan yang dikenakan oleh pihak kreditur atau pemberi pinjaman. Hal tersebutlah yang dikategorikan sebagai riba dan riba dipandang haram dalam islam. Transaksi sesuai syariah adalah transaksi yang bebas dari gharar, gharar mengandung arti yaitu adanya ketidakpastian dalam suatu transaksi. Dalam praktik umum, gharar ditemui dalam bentuk jual beli atas komoditas atas objek akad yang belum tentu jumlahnya, bentuk, dan sebagainya. Sedangkan maysir mengandung arti sepeti spekulasi atau judi. Transaksi yang bersifat maysir contohnya adalah transaksi yang didasarkan pada keinginan untuk mendapatkan keuntungan atas fluktuasi nilai suatu uang atau komoditas tertentu.

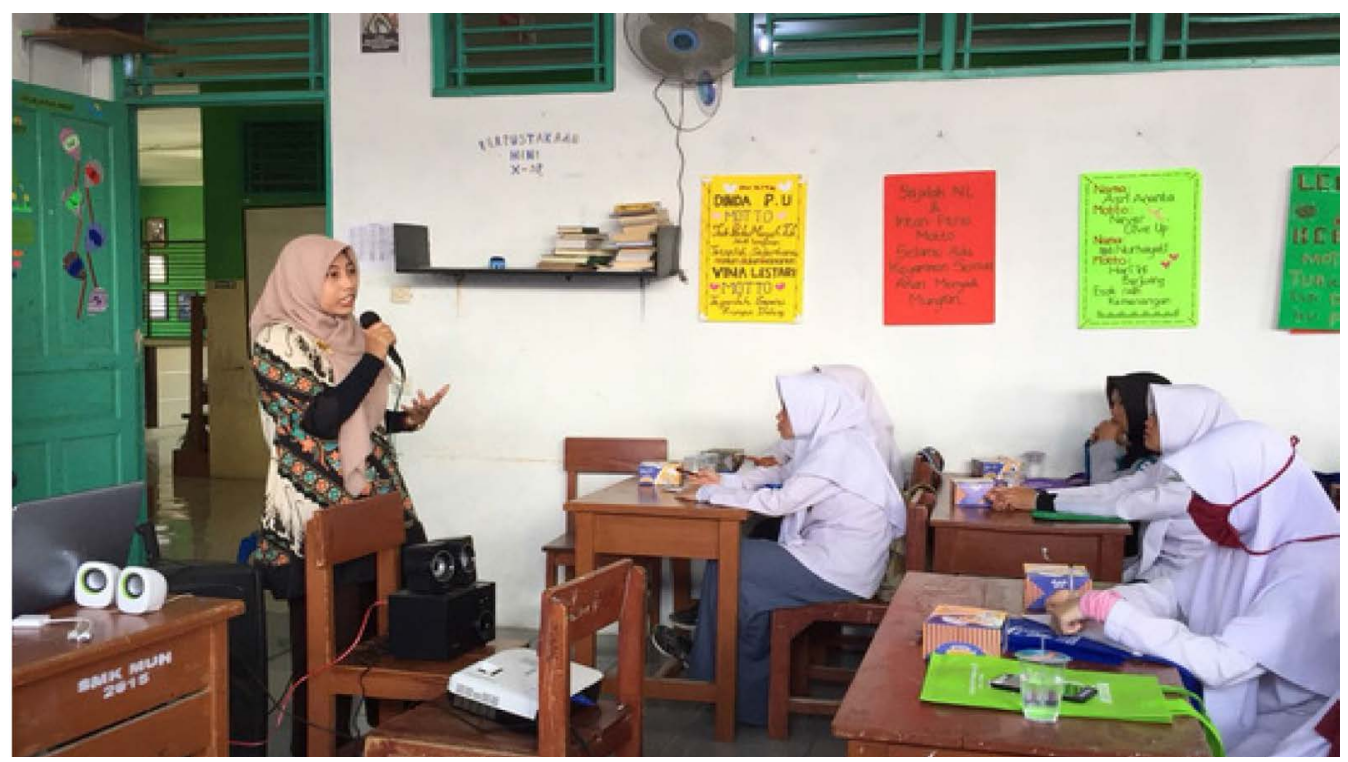

Gambar 2:

Pemaparan Keuangan Syariah dari Hera Khairunnisa

Pemateri ketiga diisi oleh Bapak Zulpahmi Dosen FEB-UHAMKA dan merupakan praktisi di lembaga keuangan syariah. Materi yang disampaiakan yaitu kerangka akuntansi syariah, proses pencatatan transaksi syariah dan jenis laporan keuangan syariah yang 
diwajibkan oleh otoritas di Indonesia. Diawal sesi pemateri ketiga, terdapat pemutaran video yang menjelaskan mengenai asal usul keuangan syariah. Pencatatan transaksi keuangan dalam islam telah diatur secara jelas. Surat Al-Baqarah 282 memiliki makna bahwa untuk mengajak orang beriman dalam melaksanakan pencatatan atau penulisan suatu muamalat yang dilakukan tidak secara tunai. Makna dari surat dalam Al-Quran terus diperjuangkan oleh umat muslim dalam membentuk sistem keuangan islam.

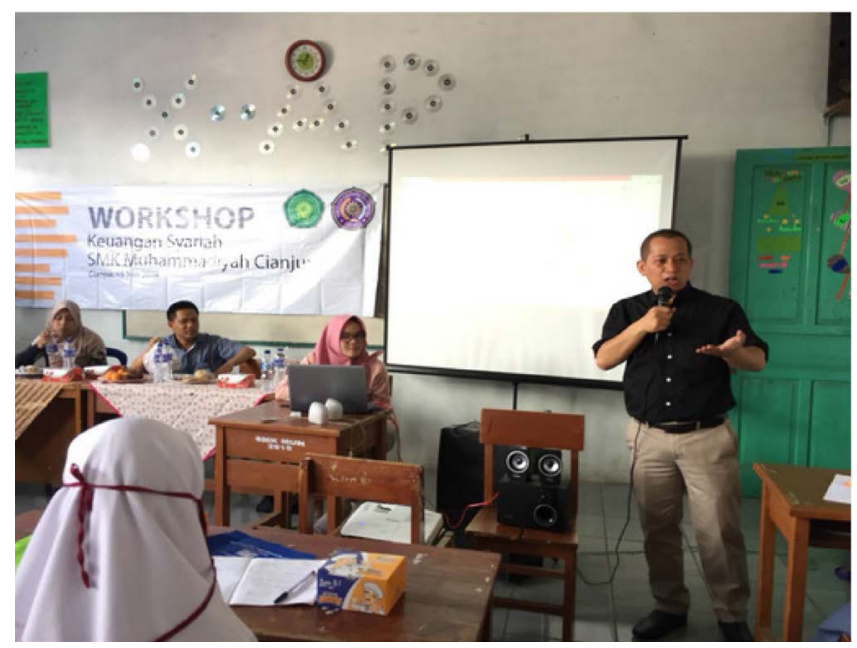

Gambar 3:

Pemaparan Keuangan Syariah dari Zulpahmi

Menurut Pernyataan Standar Akuntansi Keuangan (PSAK) 101, struktur dan isi laporan keuangan syariah terdiri dari laporan posisi keuangan, laporan laba rugi dan penghasilan komprehensif lain, laporan perubahan ekuitas, laporan arus kas, dan catatan atas laporan keuangan (CALK). Dalam PSAK 101 juga dijelaskan bahwa karakteristik umum laporan keuangan syariah terdiri dari penyajian wajar berdasarkan PSAK, asumsi akrual, materialitas dan penggabungan, saling hapus, frekuensi laporan keuangan, informasi komparatif laporan keuangan, serta konsistensi penyajian laporan keuangan.

Bapak Zulpahmi sebagai pembicara ketiga juga menjelaskan secara garis besar bahwa standar akuntansi di Indonesia sudah mengatur mengenai transaksi syariah seperti PSAK mengenai penyajian laporan keuangan syariah, akuntansi murabahah, akuntansi salam, akuntansi istishna, akuntansi mudharabah, akuntansi musyarakah, akuntansi ijarah, akuntansi transaksi asuransi syariah, dan sebagainya. Laporan posisi keuangan entitas syariah berisikan informasi atas aset, liabilitas, dana syirkah temporer, dan ekuitas. Aset dalam entitas syariah berisi kas, investasi pada surat berharga, piutang murabahah, piutang ijarah, piutang qardh, aset tetap, dan lainnya. Sementara dana syirkah temporer entitas syariah yaitu investasi tabungan mudharabah, deposito mudharabah, dan lainnya. 


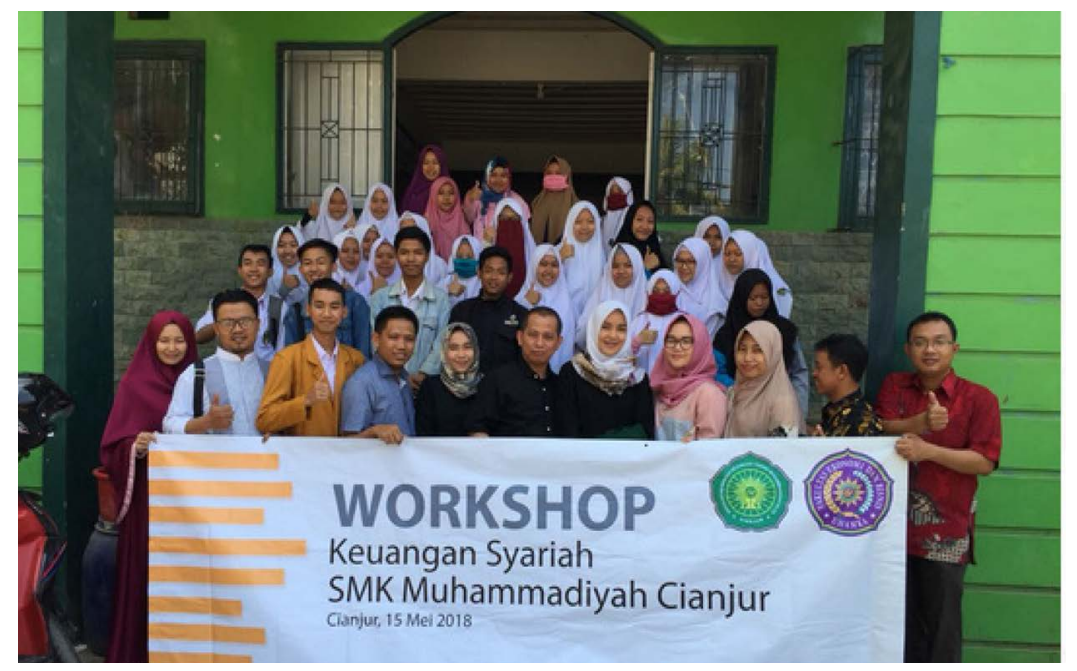

Gambar 4:

Penutupan Acara PKM di SMK Muhammadiyah Cianjur

Pemaparan materi oleh Bapak Zulpahmi juga diselingi oleh pengajuan pertanyaan yang diajukan oleh Bapak Zulpahmi kepada peserta. Hal tersebut ditujukan agar peserta lebih memahami dan tidak mudah lupa dengan pemaparan materi yang telah disampaikan oleh seluruh pembicara. Kegiatan ini juga merupakan kegiatan diskusi dua arah dan sangat dinamis.

Setelah pemaparan dari pembicara ketiga, maka pembicara membuka sesi diskusi. Siswa-siswa antusias dalam menjalani sesi ini, sesi ini dilakukan selama kurang lebih 45 menit. Pertanyaan yang diajukan oleh siswa-siswa berasal dari sekitar delapan siswa. Antusisme siswa dalam sesi pertanyaan sangat tinggi, hal tersebut dinilai dari kuantitas dan kualitas perntanyaan yang diajukan. Pertanyaan yang diajukan antara lain yaitu mengenai akad pararel dalam transaksi syariah, aspek kehalalan dalam transaksi atas penjualan saham yang beredar di sosial media, mekanisme lembaga keuangan syariah dalam memperoleh laba dan keuntungan dan sebagainya. Setelah adanya sesi diskusi, maka acara penutupan dilaksanakan disertai dengan acara ramah tamah berupa pendokumentasian acara dengan sebagian peserta yang hadir.

\section{KESIMPULAN}

Berdasarkan dari uraian di atas, perkembangan lembaga keuangan syariah sangat membutuhkan dukungan dari aspek SDM yang mencukupi baik dari segi kuantitas dan kualitas. SDM bagi lembaga keuangan syariah tidak hanya didapat dari lulusan universitas saja melainkan lulusan dari SMK yang terampil. Oleh sebab itu PKM ini merupakan bentuk dukungan nyata dari tim PKM Uhamka untuk mewujudkan kesiapan siswa-siswa SMK dalam memahami konsep ekonomi syariah dan akuntansi syariah. Kegiatan PKM 
ini telah berhasil dalam meningkatkan wawasan dari siswa-siswa SMK Muhammadiyah Cianjur. Hal tersebut terbukti dari sesi diskusi interaktif yang terdapat dalam sela-sela acara seperti pengajuan pertanyaan yang diberikan dari pembicara kepada peserta dan peserta mampu untuk menjawab dengan baik.

\section{SARAN}

Upaya pengembangan SDM untuk lapangan usaha ekonomi syariah juga membutuhkan dukungan dari pemeritah dan khususnya dari masyarakat setempat termasuk siswa-siswa SMK agar kesadaran mengimpelemtasikan ekonomi islam selalu menjadi hal yang utama dalam aktivitas sehari-hari. Sehingga pemilihan jalur karier siswasiswa SMK juga tertuju pada lembaga keuangan syariah. Saran lainnya agar pengabdian selanjutnya lebih dapat menggali lebih dalam lagi mengenai permasalahan yang ada di mitra dengan bekerjasama dengan pihak atau konsultan luar jika diperlukan.

\section{DAFTAR PUSTAKA}

Bustamam, Ibrahim, R., dan Saputra, D. 2015. Analisis Penyajian Laporan Keuangan Syariah pada Baitul Mal Provinsi Aceh. Jurnal Dinamika Akuntansi dan Bisnis, Vol 2(1), 82-91.

Harahap, S., S., Wiroso, dan Yusuf, M. 2010. LPFE Usakti

Wiroso. 2013.

Indriyanti, N., Siswandari, dan Ivada, E. 2013. Faktor-faktor yang Memengaruhi Minat

Melanjutkan Pendidikan ke Perguruan Tinggi pada Siswa Kelas XII Akuntansi SMK Negeri 6 Surakarta Tahun 2013. Jupe UNS, 1(2), 1-10.

Maharani, R., Nuraini, F., Andrianto. 2017. Analisis Perbedaan Persepsi Akademisi Akuntansi terhadap Penerapan Mata Kuliah Akuntansi Syariah (Studi Kasus pada Universitas Muhammadiyah Surabaya). Jurnal Ekonomi dan Bisnis Islam, Vol $3(1), 39-48$.

Rahmanti, V., N. 2012. Sebuah Kajian Mengapa Akuntansi Syariah Masih Sulit Tumbuh Subur di Indonesia. Jurnal Akuntansi \& Investasi, Vol 13(2), 161-179.

Setiawan., I., K., Y. 2015. Pengaruh Latar Belakang Pendidikan dan Pengalaman Kerja terhadap Kinerja Karyawan pada PT. Federal International Finance (FIF) Group Cabang Singaraja. Jurnal Jurusan Pedidikan Ekonomi, 5(1), 1-11.

Widiana. 2017. Analisis Perkembangan Peraturan dan Penerapan Akuntansi Syariah di Indonesia. Jurnal Law and Justice, Vol 2(1), 35-43.

http://www.smkm-cianjur.sch.id/

https://www.smkbhaktinusantarasalatiga.sch.id/perbankan-syariah/ 